Journal of Engineering and Applied Sciences 14 (15): 5267-5281, 2019

ISSN: 1816-949X

(C) Medwell Journals, 2019

\title{
Flexural Behavior and Mechanical Properties of Steel Fibers Ferro Geopolymer One Way Slabs Mortar
}

\author{
Wissam D. Salman, Safie Mahdi Oleiwi and Ahmed Abdullah Mansor \\ Department of Civil Engineering, Universityof Diyala, Baquba, Iraq
}

\begin{abstract}
The flexural behavior, elastic and properties of steel fiber reinforced geopolymer mortar were experimentally investigated in this study. Geopolymer mortar mixes were arranged by low calcium fly ash and it is activated by using $\left(\mathrm{NaOH}\right.$ and $\left.\mathrm{Na}_{2} \mathrm{SiO}_{3}\right)$ alkaline solutions with 0.4 ratio from fly ash solution. Alkaline activator is prepared by mixing of 10 molarity of $\mathrm{NaOH}$ solution with $\mathrm{Na}_{2} \mathrm{SiO}_{3}$ in 1:2.5 ratio. Steel fibers were added at various volume of fractions for the geopolymer mortar of $(0-3 \%)$ at an interval of $(0.25 \%)$ by mix volume. Effectiveness of steel fiber content was assessed according to properties of geopolymer mortar such as (workability, fresh unit weight, flexural, compressive and splitting tensile strengths) and the flexural behavior of thin ferro geopolymer slab with welded square wire mesh is presented. Test results showed that steel fiber enhanced the mechanical properties of geopolymer mortar, particularly for the flexural and splitting tensile strengths. As well as adding steel fibers improved the flexural resistance of ferro geopolymer slab $2.25 \%$ increased the load capacity with $155.59 \%$ and decreased in deflection $75.18 \%$ as well as caused delay in crack growth and crack width is decreased, however, number of cracks is increased. Using steel fiber in ferro geopolymer slabs increased the ductility of because of introduction of steel fiber in the mix.
\end{abstract}

Key words: Flexural behavior, geopolymer mortar, slab motors, mechanical properties, ferro geopolymer slabs, steel fiber reinforced mortar

\section{INTRODUCTION}

By increasing economic and conservational concerns related with conservative concrete construction materials, for example, reinforced concrete buildings, researchers have been associated with investigating conceivable outcomes in utilizing elective materials to address these worries. As example, recycled concrete aggregate consider analternative materials of production concrete have been attempted in reinforced concrete buildings (Li, 2009; Xiao et al., 2012) as well as materials of agriculture waste (Mo et al., 2014) between others in a trailed to decrease the dependence on predictable concrete basic materials. High amount of carbon dioxide production considers that main of environmental apprehensions from concrete materials that rises through the production of cement and it is contribute with $5 \%$ of the global carbon dioxide production during cement production (Mo et al., 2016). A production of geopolymer is a procedure named "geopolymerization" is obligatory that contains activation between aluminosilicate material and alkaline liquids. Communal aluminosilicate material depend to manufacture geopolymer is slag and fly ash which are both have low carbon dioxide emission factor compared with cement (Mo et al., 2016). By using geopolymer can minimize the carbon dioxide emission by up to $64 \%$ in comparison with using cement (McLellan et al., 2011). Also, fly ash is lower fee with $10-30 \%$ compared to cement based concrete after consideration the alkaline liquids price (Lloyd and Rangan, 2010). Geopolymer is amorphous to semicrystalline equivalent of confident zeolitic materials by high performance characteristics for example high fire, corrosion resistances and high strength materials (Rajendran and Soundarapandian, 2013). Mostly utilized alkaline activators consist of sodium hydroxide or potassium hydroxide $(\mathrm{NaOH}$ or $\mathrm{KOH})$ with sodium water glass or potassium water glass. The concentration of $\mathrm{NaOH}$ solution can be used in the range of 8-16 molar (Pan et al., 2009).

Fiber reinforced concrete is made by Portland cement, aggregates and separate intermittent fibers. Plain and unreinforced concrete is identified as a stiff material with a little strain and little tensile strength (Lin et al., 2011) and the cracks usually growas a result of some reasons, for example, plastic and drying shrinkages in

Corresponding Author: Wissam D. Salman, Department of Civil Engineering, University of Diyala, Baquba, Iraq 
pre-hardening and hardened concrete, respectively. Then these cracks deteriorate competences of concrete water proofing, exposing the concrete microstructure to destructive substances such as sulfates, chloride, moisture, bromine, etc. (Koksal et al., 2008; Song et al., 2005; Sivakumar and Santhanam, 2007; Toutanji, 1999). Consequently, upgrading characteristics of hardened concrete is a significant aim in concrete technology (Nili and Afroughsabet, 2012). Fibers added into cementitious concretes to improved durability properties and increased tensile strength, ductility, toughness (Kuder and Shah, 2010; Balaguru and Shah, 1992; Lau and Anson, 2006; Vogel and Svecova, 2012 and Ezeldin and Balaguru, 1989). The efficiency of the fiber is reliant on some issues, for example, the properties of the fiber matrix, inclusion, geometry, volume, type and orientation of fiber in the concrete mixture (Yurtseven, 2004; Ganesan et al., 2013). The fibers are mainly made of steel, glass and synthetic fibers (Hassanpour et al., 2012; Barros and Cruz, 2001; Ghavami, 2005). Earlier studies show that adding fibers improves the mechanical properties of geopolymer concrete (Gokulram and Anuradha, 2013; Srinivasan et al., 2013; Vijai et al., 2012; Kumar et al., 2012; Bernal et al., 2010 and Sayyad and Patankar, 2013). Researches founded that replace the cementbased binder in fiber reinforced concrete with "geopolymeric" binder resulting in Fiber Reinforced Geopolymer Composites (FRGCs) which is greener than the former one (Rekha and Hazeena, 2014). The performance of fiber reinforced composites depends on the properties of the matrix and the fibers (Aydin and Baradan, 2013). Bernal et al. (2010) assessed the mechanical and permeability properties of Alkali Activated Slag Concrete (AASC) reinforced with steel fibers at content of 0.5 and $1.5 \%$. The results showed that AASC reinforced with steel fibers exhibits improved mechanical performance rather than ordinary portland cement concrete. Natali et al. (2011) studied the effect of different fiber types on the flexural performance on fiber reinforced geopolymer composite (Carbon, glass, Polyvinyl Alcohol (PVA) and Polyvinyl Chloride (PVC)) and the experimental results presented that used of all fiber types enhanced the flexural strength and post-crack ductility.

"Ferrocement is consider a thin concrete wall reinforced with small size wire mesh could be manufactured by metallic and suitable materials (Phalke and Gaidhankar, 2014). Nervi who first used the term ferrocement its famous properties are "larger elasticity and reduce to cracking of cement mortar by the extreme portion and reinforcement distribution"
(Balaguru and Batson, 1997). Ferrocement is used for the construction of folded plates, domes, vaults and grid surfaces (Rajendran and Soundarapandian, 2013). Usually, thickness of ferrocement shells ranged from $10-40 \mathrm{~mm}$ and consists of steel mesh layers as a reinforcement. There are many applications of ferrocement panels because of availability, fabricated for any shape, high durability than other materials, easily acquired qualifications need for construction and it is less capital-intensive but more labor intensive (Rao et al., 2008; Abdullah et al., 2013). Increasing of strength of the ferrocement depend to increase reinforcement ratio but if the ratio is high, strength of ferrocement decreases because the mortar cannot be simply forced inside without founding voids (Sudhikuma et al., 2014).

This study investigated effect of used the steel fiber ratio for 13 mixtures as well as the geopolymer mortar properties of such as compressive, splitting tensile and flexural strengths were assessed to found the optimum percentage of steel fibers. The steel fiber ratio was used from $0-3 \%$ with an increase of $0.25 \%$ of the volume of geopolymer mortar. The aimed of this study to investigating the structural behavior of fiber reinforced mortar as this material is widely used in various applications such as ferro-geopolymer mortar slab.

\section{MATERIALS AND METHODS}

Experimentalprogram: Experimental work involved study the steel fibers content effect on flexural behavior, mechanical and elastic properties on geopolymer mortar. The materials used for making fly ash-based geopolymer mortar composite specimens and ferro geopolymer slab panel are low-calcium fly ash, fine aggregates, steel fibers, alkaline solution, wire mesh and water.

\section{Properties of materials}

Fly Ash (FA): FA is used in place of bounding supplies to improve geopolymer mortar. Class F from FA is provided from Ceyhan Sugozu thermal power plant according to ASTM C618 (ASTM, 2003). Table 1 presented the properties of FA as obtained by X-Ray Fluorescence (XRF). Rangan (2008) it can be seen that chemical composition of the FA is well-matched with the class F fly ashes that used in researches existing in the literature (ASTM, 2003; Rangan, 2008; Joseph and Mathew, 2012).

Alkaline solution: The antacid activator is a blend of $10 \mathrm{M}$ of $\mathrm{NaOH}$ arrangement with sodium silicate with 


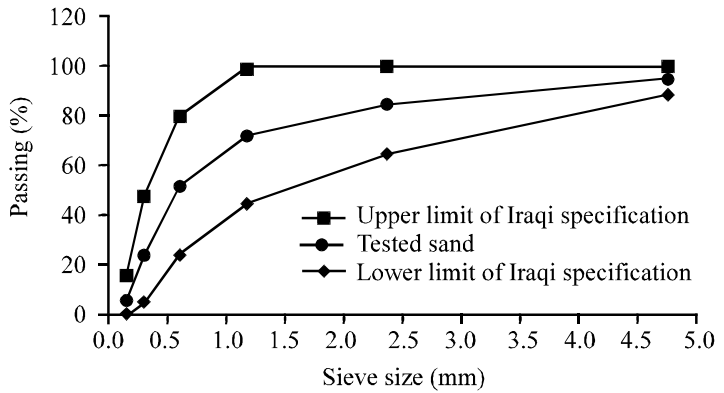

Fig. 1: Sieve analysis of fine aggregate

\begin{tabular}{lr} 
Table 1: Fly ash properties & \\
\hline Physical and chemical analysis (\%) & FA \\
\hline $\mathrm{CaO}$ & 2.20 \\
$\mathrm{SiO}_{2}$ & 57.20 \\
$\mathrm{Al}_{2} \mathrm{O}_{3}$ & 24.40 \\
$\mathrm{Fe}_{2} \mathrm{O}_{3}$ & 7.10 \\
$\mathrm{MgO}$ & 2.40 \\
$\mathrm{SO}_{3}$ & 0.30 \\
$\mathrm{~K}_{2} \mathrm{O}$ & 3.40 \\
$\mathrm{Na}_{2} \mathrm{O}$ & 0.40 \\
Loss ignition & 1.50 \\
Specific gravity & 2.25 \\
Specific surface area $\left(\mathrm{m}^{2} / \mathrm{kg}\right)$ & 379.00 \\
\hline
\end{tabular}

Table 2:Sieve analysis of fine aggregate

\begin{tabular}{lcc}
\hline Sieve size (mm) & Cumulative passing (\%) & $\begin{array}{c}\text { Cumulative passing limits of } \\
\text { Iraqi specifications (Iraqi } \\
\text { Standard Specifications, } \\
\text { 1984) zone (2) (\%) }\end{array}$ \\
\hline 4.75 & 95 & $90-100$ \\
2.36 & 85 & $75-100$ \\
1.18 & 72 & $55-90$ \\
0.60 & 52 & $35-59$ \\
0.30 & 24 & $8-30$ \\
0.15 & 5 & $0-10$ \\
\hline
\end{tabular}

*The test was carried out at the laboratory of construction materials at College of Engineering, Diyala University

Table 3: Properties of fine aggregate

\begin{tabular}{lcc}
\hline Properties & Test results & Limit of specification \\
\hline Sulfate content as $\mathrm{SO}_{3}(\%)$ & 0.11 & .0 .5 \\
Absorption (\%) & 2.20 & - \\
Specific gravity & 2.65 & - \\
\hline
\end{tabular}

proportion of $1: 2.5$. The proportion of antacid answer for fastener equivalent to 0.40 . $\mathrm{NaOH}$ as drops were utilized to create $\mathrm{NaOH}$ arrangement. The synthesis of $\mathrm{Na}_{2} \mathrm{SiO}_{3}$ arrangement is $29.4 \% \mathrm{SiO}_{2}, 14.7 \% \mathrm{Na}_{2} \mathrm{O}$ and $55.99 \%$ water (by mass).

Aggregates: Afine aggregate with maximum size of $4.75 \mathrm{~mm}$ was used. Table 2 and Fig. 1 explain the sieve analysis of sand used in this study. Results show that the sand properties are with in the Iraqi specification No.45/1984 (Iraqi Standard Specifications, 1984) requirements. Table 3 illustrates the properties of fine aggregate used.

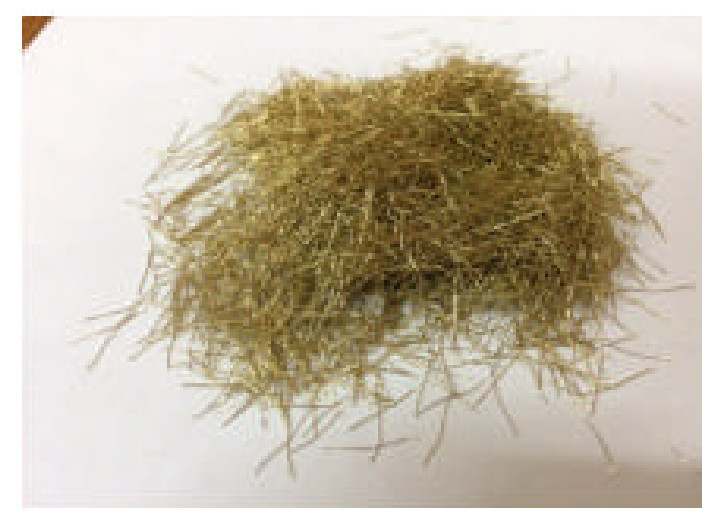

Fig. 2: Straight steel fiber

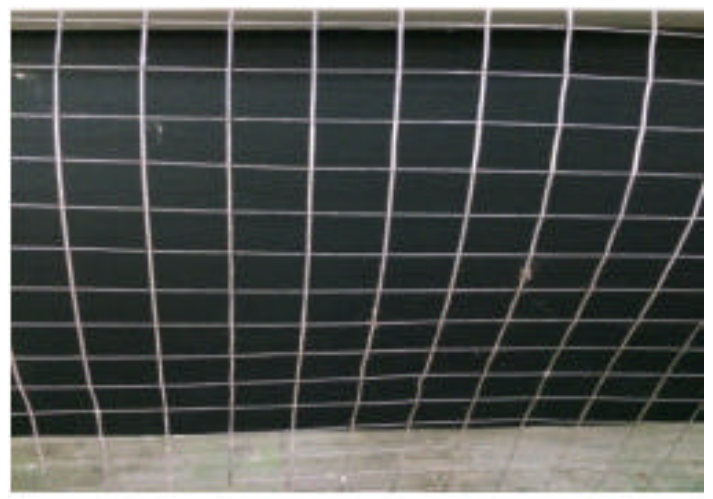

Fig. 3: Square wire mes

Steel fibers: Straight steel fibers with aspect ratio (L/d) 65 is used with modulus of Elasticity (E) of $210 \mathrm{GPa}$ (Fig. 2).

Wire mesh: Locally available woven chicken wire mesh of $0.6 \mathrm{~mm}$ diameter and square openings with a distance of $15 \times 15 \mathrm{~mm}$ (Fig. 3) used in a 4-layers as main reinforcement for ferro-geopolymer slab panel.

Water: For both mixing and curing, tap water was used.

Mix proportion: Atrial mixing was doing to obtain targeted cubic compressive strength of $25 \mathrm{MPa}$ for the mortar without steel fibers. There are thirteen different steel fiber contents used in geopolymer mortar, namely 0 , $0.25,0.5,0.75,1.0,1.25,1.50,1.75,2.0,2.25,2.50,2.75$ and $3.0 \%$ adding by volume while for the ferro-geopolymer slab panel there is the control specimen without steel fiber and specimens with $(1.0,2.0,2.25$ and $3.0 \%)$ steel fiber volume. Figure 4 shows the preparation of geopolymer mortar and ferro-geopolymer slab. 
(a)

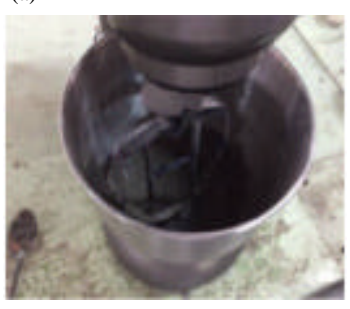

(b)

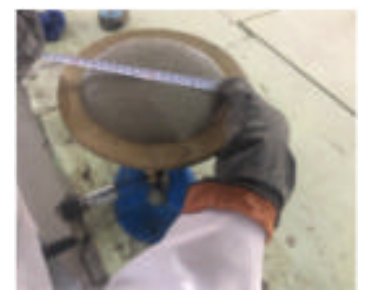

(c)

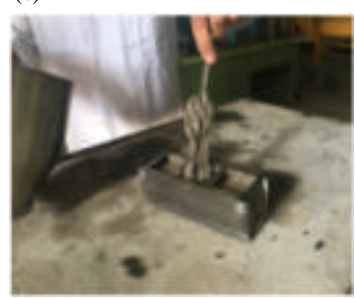

(d)

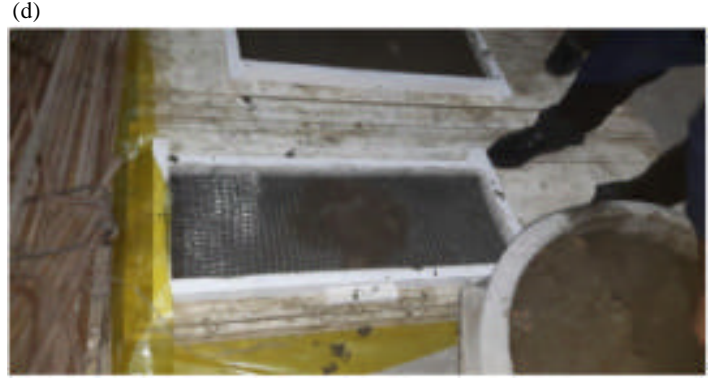

Fig. 4: Preparation of geopolymer mortar and ferro geopolymer slab; a) Mixing of geopolymer mortar; b) Geopolymer mortar flow table test; c) Casting the geopolymer mortar in cubes and d) Casting of ferro geopolymer sab

\begin{tabular}{|c|c|c|c|c|c|c|c|}
\hline $\begin{array}{l}\text { Mix. designation } \\
\text { (SF) }\end{array}$ & $\begin{array}{l}\text { Steel fiber content } \\
\text { (SF) }\end{array}$ & $\begin{array}{l}\text { Fly ash } \\
\left(\mathrm{kg} / \mathrm{m}^{3}\right)\end{array}$ & $\begin{array}{l}\text { Sand } \\
\left(\mathrm{kg} / \mathrm{m}^{3}\right)\end{array}$ & $\begin{array}{l}\text { NaoH solution } \\
\left(\mathrm{kg} / \mathrm{m}^{3}\right)\end{array}$ & $\begin{array}{l}\mathrm{Na}_{2} \mathrm{Sio}_{3} \text { solution } \\
\left(\mathrm{kg} / \mathrm{m}^{3}\right)\end{array}$ & $\begin{array}{c}\text { Extra water } \\
\left(\mathrm{kg} / \mathrm{m}^{3}\right)\end{array}$ & $\begin{array}{c}\text { Steel fiber: } \\
\left(\mathrm{kg} / \mathrm{m}^{3}\right)\end{array}$ \\
\hline GM-0 & 0 & 700 & 1400 & 80 & 200 & 115 & 0.0 \\
\hline GM- 0.25 & 0.25 & 700 & 1380 & 80 & 200 & 115 & 19.5 \\
\hline GM- 0.50 & 0.50 & 700 & 1361 & 80 & 200 & 115 & 39.0 \\
\hline GM- 0.75 & 0.75 & 700 & 1341 & 80 & 200 & 115 & 58.5 \\
\hline GM-1.00 & 1.00 & 700 & 1322 & 80 & 200 & 115 & 78.0 \\
\hline GM-1.25 & 1.25 & 700 & 1302 & 80 & 200 & 115 & 97.5 \\
\hline GM-1.50 & 1.50 & 700 & 1283 & 80 & 200 & 115 & 117.0 \\
\hline GM-1.75 & 1.75 & 700 & 1263 & 80 & 200 & 115 & 136.5 \\
\hline GM-2.00 & 2.00 & 700 & 1244 & 80 & 200 & 115 & 156.0 \\
\hline GM-2.25 & 2.25 & 700 & 1224 & 80 & 200 & 115 & 175.5 \\
\hline GM-2.50 & 2.50 & 700 & 1205 & 80 & 200 & 115 & 195.0 \\
\hline GM-2.75 & 2.75 & 700 & 1185 & 80 & 200 & 115 & 214.5 \\
\hline GM-3.00 & 3.00 & 700 & 1166 & 80 & 200 & 115 & 234.0 \\
\hline
\end{tabular}

Table 5: Ferro-geopolymer slab panel details \begin{tabular}{lll}
\hline Specimen $(\mathrm{SF})$ & Steel fiber $(\%)$ & No. of wire mesh layer \\
\hline
\end{tabular} FGS 0 SF

FGS $1 \mathrm{SF}$

FGS $2 \mathrm{SF}$

FGS $3 \mathrm{SF}$

FGS $2.25 \mathrm{SF}$

Mixing, casting and curing of mortar: Particles of $\mathrm{NaOH}$ was liquified in refined water for $24 \mathrm{~h}$ prior to obtained the suitable concentration of the solution. Fly ash, steel fibers and fine aggregate are initially mixed together in dry state for about $3 \mathrm{~min}$ and then the liquid component of the mixture is added to prepare wet mix till it gives homogeneous mix. Mix amount of geopolymer mortar per cubic meter are given in Table 4. Details of ferro-geopolymer slab panel is presented in Table 5 . The fresh geopolymer mortar was cased in 2 layers in molds (cubes is $50 \times 50 \times 50 \mathrm{~mm}^{3}$ and for prismsare $40 \times 40 \times 160 \mathrm{~mm}^{3}$ ). After casting, the molds were vibrated by table vibrating for $30 \mathrm{sec}$. The experiments were performed on geopolymer mortar specimens (cubes and prism) and for ferro-geopolymer slabs below curing temperatures of $80^{\circ} \mathrm{C}$ with $24 \mathrm{~h}$ period. After process of curing, all specimens were demolded and the specimens were tested. A total of 78 cubes, 36 prims and 5 slabs specimens were obtained.

Geometry of ferro geopolymer slab panel: A one-way slabpanel with $750 \times 300 \times 40 \mathrm{~mm}$ dimensions is used. Table 5 presented the designation of the slabs. The slabs are made by using the conservative materials which is composed of square wire mesh, steel fiber as well as geopolymer mortar. Figure 5 shows the geometry of ferro-geopolymer slab panel.

Casting and curing of ferro geopolymer slabs: Wood mold fabricated used to match the shape and size of the 


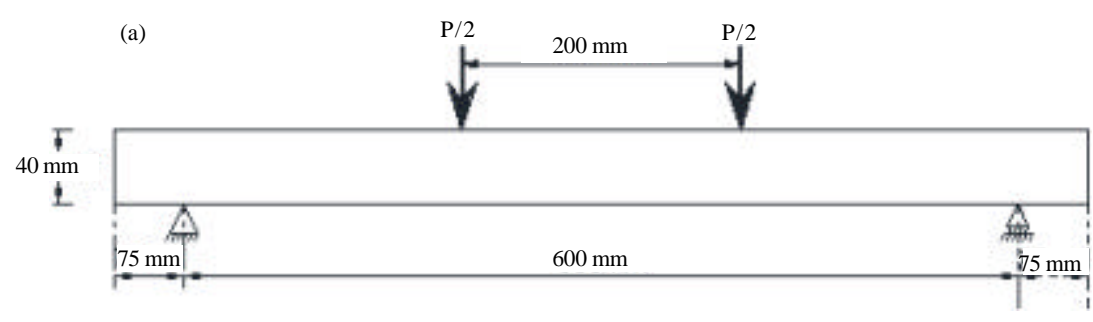

(b)
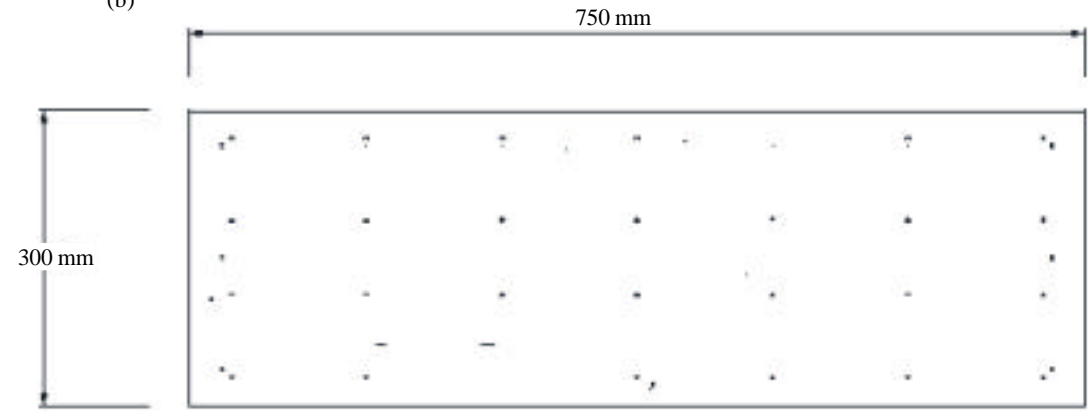

Fig. 5: Geometry of ferro geopolymer slab panel specimens: a) Cross section and b) Topview

slab panel. The specimen was cast after fixing the wire mesh in correct location in the mold. All ferro geopolymer slabs were heat curing space for $24 \mathrm{~h}$ at $80^{\circ} \mathrm{C}$. The primary variable is the steel fiber content $(0,1,2,2.25$ and $3 \%$ ).

\section{Procedures of testing}

Flow table: Flow table test according to ASTM C1437 was depend to measure workability of fresh geopolymer mortar as explained in the Fig. $4 \mathrm{~b}$, the dimensions of cone are 70 $100 \mathrm{~mm}$ in top and bottom diameter and $60 \mathrm{~mm}$ height diameter

Two layers of mortar depend and each layer packed 20 times by temper and leveled the top surface and flow table dropped 25 times in $15 \mathrm{sec}$. Workability of mortar estimated by measuring 4 symmetrically diameters in 2 axes.

Fresh unit weight: ASTM C138 specification depend to determine the unit weight of the mortar by using the known cubic mold volume. The cube weight measured separately when it empty and the filled with freshly mixed mortar. The following equation depend to compute the unit weight:

$$
\text { Unit weight }=\frac{\mathrm{Mf}-\mathrm{Me}}{\mathrm{V}}
$$

Where:

Mf $=$ Weight of mortar and mold

$\mathrm{Me}=$ Weight of empty mold

$\mathrm{V}=$ Mold Volume
Compressive strength: ASTM C109 depend to predicted the compressive strength predicted of cement mortar cubes. The cub molds filled by half and $30 \mathrm{sec}$ vibrated then filling it by rest of mortar and re-vibrated again for $30 \mathrm{sec}$ then leveling top of molds. The molds covered by PVC sheet plastic and by vacuum wrapping. After mixing the molds sited in oven for $24 \mathrm{~h}$ at $80^{\circ} \mathrm{C}$. Three identical specimens were tested by a $2000 \mathrm{kN}$ digital compressive testing machine.

Splitting tensile strength: Three specimen's cubes with $50 \times 50 \times 50 \mathrm{~mm}$ dimensions were splitting tensile strength tested for every mixture according to ASTM C37 with a loading rate $0.1 \mathrm{kN} / \mathrm{sec}$, using $2000 \mathrm{kN}$ capacity. The strength of splitting tensile was calculated using the expression:

$$
\mathrm{fs}=\frac{2 \mathrm{P}}{\pi \mathrm{a} 2}
$$

Where:

$$
\begin{aligned}
& \mathrm{P}=\text { Splitting load }(\mathrm{N}) \\
& \mathrm{fs}=\text { Splitting strength }(\mathrm{MPa}) \\
& \mathrm{a}=\text { Cubic dimension }(\mathrm{mm})
\end{aligned}
$$

Flexural strength test: According to (ASTM C348-14) three prisms with $(40 \times 40 \times 160 \mathrm{~mm})$ dimensions were used to measure the flexural strength and according the Eq. 3 the modulus of rupture was calculated:

$$
\mathrm{R}=\frac{3 \mathrm{PL}}{2 \mathrm{bh}_{2}}
$$




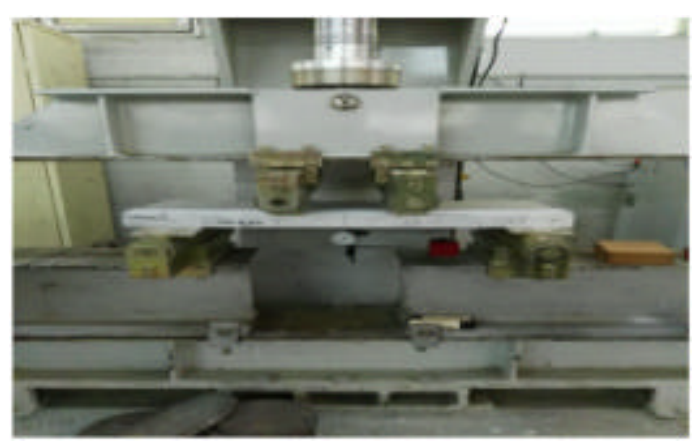

Fig. 6: Test set-up of ferro geopolymer slab

Where:

$\mathrm{P}=$ Max. applied load $(\mathrm{N})$

$\mathrm{L}=$ Length of $\operatorname{span}(\mathrm{mm})$

$\mathrm{R}=$ Modulus of rupture (MPa)

$\mathrm{b}=$ Specimen width $(\mathrm{mm})$

$\mathrm{h}=$ Specimen depth $(\mathrm{mm})$

Testing of ferro geopolymer slabs: After heat curing, the slabs specimens are tested under $600 \mathrm{kN}$ hydraulic jack and simulating as simply supported settings. Applied load was arranged as two symmetrically concentrated loads. The deflection was measured by fixed a dial gauge (0-50 $\mathrm{mm}$ ) at central bottom. Cracking was carefully measured throughout the loading process by microcracks. All specimens painted by white color to help in tracing the cracks. Figure 6 present the setup of testing.

\section{RESULTS AND DISCUSSION}

Steel fiber geopolymer mortar properties (fresh): The workability of steel fibers geopolymer mortar was evaluated by measure the flow diameter after completing mixing of geopolymer mortar immediately. Table 6 presented the criteria of geopolymer mortar depend to flow diameter (Mermerdas et al., 2017). It can be seen that the minimum flow diameter for geopolymer mortar is $150 \pm 10 \mathrm{~mm}$. Flow is a combination of some properties involving consistency, cohesion and plasticity. It is difficult measure cohesions and plasticityin site. However, consistency is regularly depending to measure the workability. Table 7 shows that the work ability of geopolymer mortar was effected bysteel fiber ratio, however, the work ability was decreased by the steel fiber ratio increasing in geopolymer mortar. By using larger amount of steel fiber ratio, the flow of geopolymer mortar was decreased. Also, it was found by using 3\% steel fiber
Table 6: Criteria of geopolymer mortar workability (Mermerdas ${ }_{\star \alpha .}, 2017$ )

\begin{tabular}{ll}
\hline Flow diameter $(\mathrm{mm})$ & Workability \\
\hline Below 120 & Very stiff \\
$120-150$ & Stiff \\
$150-180$ & Moderate \\
$180-250$ & High \\
Above 250 & Very high \\
\hline
\end{tabular}

the mortar flow will be reduced, so, it needs more alkaline activator to obtain a suitable flow compared to geopolymer mortar mix without steel fiber.

Figure 7 shows the result of flow table test for fresh geopolymer mortar. It can be seen that without steel fibers (GM-OSF), the flow rate is $230 \mathrm{~mm}$ and by using 3\% steel fibers (GM-3.0SF) the flow rate is $155 \mathrm{~mm}$. Examination of Table 7 indicates that the workability of geopolymer mortar including steel fiber reduces with increases in fiber content. It might be due to viscous nature of geopolymer mortar and uneven distribution of fibers in the mix. The maximum decrease in flow is 32.6 at $3.0 \%$ of steel fiber content. Figure 8 shows reducing of workability values by increasing steel fibers ratio from GM-OSF to GM-3.OSF. This agrees with the results of the previous studies that the workability will be decreases as a result of steel fibers ratio increases (Day and Shi, 1994; Shannag and Yeginobali, 1995; Kaid et al., 2009; Toutanji et al, 2004 and Hardjito and Rangan, 2005).

Directly after mixing, the fresh density of geopolymer mortar with steel fiber was conducted and measured for all mixtures. Figure 9 presented the relation between the steel fibers ratios and fresh unit weight of geopolymer mortar. As shown in Fig. 9 and 10 there was significant that the unit weight of mortar increased by increase the steel fiber ratio because of steel fiber has a large unit weight than reference geopolymer mortar (without steel fiber). Density value for GM-OSF and GM-3.OSF are 2210 and $2500 \mathrm{~kg} / \mathrm{m}^{3}$, respectively. It is confirmed that as the density increased according to increasing loading of steel fibers. Table 7 and Fig. 10 show that inclusion of steel fibers increases the density of concrete due to good particle packing and reduction in air content. The maximum increase in wet density is $13.12 \%$.

Mechanical properties of hardened steel fiber geopolymer mortar: Table 8 presented the mechanical properties of steel fibers geopolymer mortar and Fig. 11-16. It was showed that the presence of fiber steel usually enhanced the mechanical properties of the geopolymer mortar. However, the increase in the compressive strength was a lower range associated to the flexural strengths and splitting tensile. This issue may be 
Table 7: Fresh properties of steel fiber geopolymer mortar

\begin{tabular}{llccccc}
\hline Mix. designation (SF) & Steel fiber content (SF) & Flow $(\mathrm{mm})$ & Flow $(\%)$ & Decrease in flow $(\%)$ & Fresh density $\left(\mathrm{kg} / \mathrm{m}^{3}\right)$ & Increase in density $(\%)$ \\
\hline GM-0 & 0 & 230 & 130 & Ref. & 2210 & Ref. \\
GM- 0.25 & 0.25 & 220 & 120 & 4.35 & 2230 & 0.90 \\
GM-0.5 & 0.50 & 210 & 110 & 8.70 & 2250 & 1.81 \\
GM-0.75 & 0.75 & 205 & 105 & 10.87 & 2280 & 3.17 \\
GM-1.0 & 1.0 & 200 & 100 & 13.04 & 2300 & 4.07 \\
GM-1.25 & 1.25 & 195 & 95 & 15.22 & 2320 & 6.98 \\
GM-1.5 & 1.50 & 190 & 90 & 17.39 & 2350 & 7.33 \\
GM-1.75 & 1.75 & 185 & 85 & 19.57 & 2380 & 8.60 \\
GM-2.0 & 2.0 & 180 & 80 & 21.74 & 2400 & 9.95 \\
GM-2.25 & 2.25 & 175 & 75 & 23.91 & 2430 & 10.86 \\
GM-2.5 & 2.50 & 170 & 70 & 26.09 & 2450 & 1.76 \\
GM-2.75 & 2.75 & 160 & 60 & 30.43 & 2470 & 13.12 \\
GM-3.0 & 3.0 & 155 & 55 & 32.61 & 2500 & \\
\hline
\end{tabular}

Table 8: Mechanical properties of steel fiber geopolymer mortar

\begin{tabular}{llcccccc}
$\begin{array}{l}\text { Mix. } \\
\text { designation (SF) }\end{array}$ & $\begin{array}{l}\text { Steel fiber } \\
\text { content }(\mathrm{SF})\end{array}$ & $\begin{array}{c}\text { Compressive strength } \\
\left(\mathrm{f}_{\mathrm{cu}} \mathrm{MPa}\right)\end{array}$ & $\begin{array}{c}\text { Splitting tensile } \\
\text { strength }\left(\mathrm{f}_{\mathrm{t}} \mathrm{MPa}\right)\end{array}$ & $\begin{array}{c}\text { Flexural strength } \\
\left(\mathrm{f}_{\mathrm{r}} \mathrm{MPa}\right)\end{array}$ & $\begin{array}{c}\text { Increase in } \\
\left(\mathrm{f}_{\mathrm{cu}}\right)(\%)\end{array}$ & $\begin{array}{c}\text { Increase in } \\
\left(\mathrm{f}_{t}\right)(\%)\end{array}$ & $\begin{array}{c}\text { Increase in } \\
\left(\mathrm{f}_{\mathrm{r}}\right)(\%)\end{array}$ \\
\hline GM-0 & 0 & 27.67 & 2.76 & 6.02 & Ref. & Ref. & Ref. \\
GM-0.25 & 0.25 & 29.73 & 2.83 & 6.10 & 7.46 & 2.42 & 1.33 \\
GM-0.50 & 0.50 & 30.57 & 2.95 & 6.15 & 10.47 & 6.76 & 2.10 \\
GM-0.75 & 0.75 & 33.51 & 3.33 & 8.23 & 21.11 & 20.65 & 36.66 \\
GM-1.00 & 1.00 & 35.61 & 3.65 & 8.81 & 28.70 & 32.37 & 46.35 \\
GM-1.25 & 1.25 & 36.56 & 4.81 & 11.56 & 32.12 & 74.15 & 92.08 \\
GM-1.50 & 1.50 & 40.55 & 5.13 & 13.56 & 46.56 & 85.99 & 125.30 \\
GM-1.75 & 1.75 & 41.44 & 5.97 & 14.70 & 49.78 & 116.43 & 144.13 \\
GM-2.00 & 2.00 & 47.10 & 6.16 & 17.08 & 70.21 & 123.19 & 183.67 \\
GM-2.25 & 2.25 & 50.30 & 6.67 & 18.52 & 81.79 & 141.67 & 207.59 \\
GM-2.50 & 2.50 & 45.56 & 6.61 & 16.91 & 64.67 & 139.49 & 180.90 \\
GM-2.75 & 2.75 & 43.33 & 6.15 & 16.71 & 56.61 & 122.71 & 177.52 \\
GM-3.00 & 3.00 & 42.52 & 6.02 & 15.13 & 53.68 & 118.24 & 151.33 \\
\hline
\end{tabular}

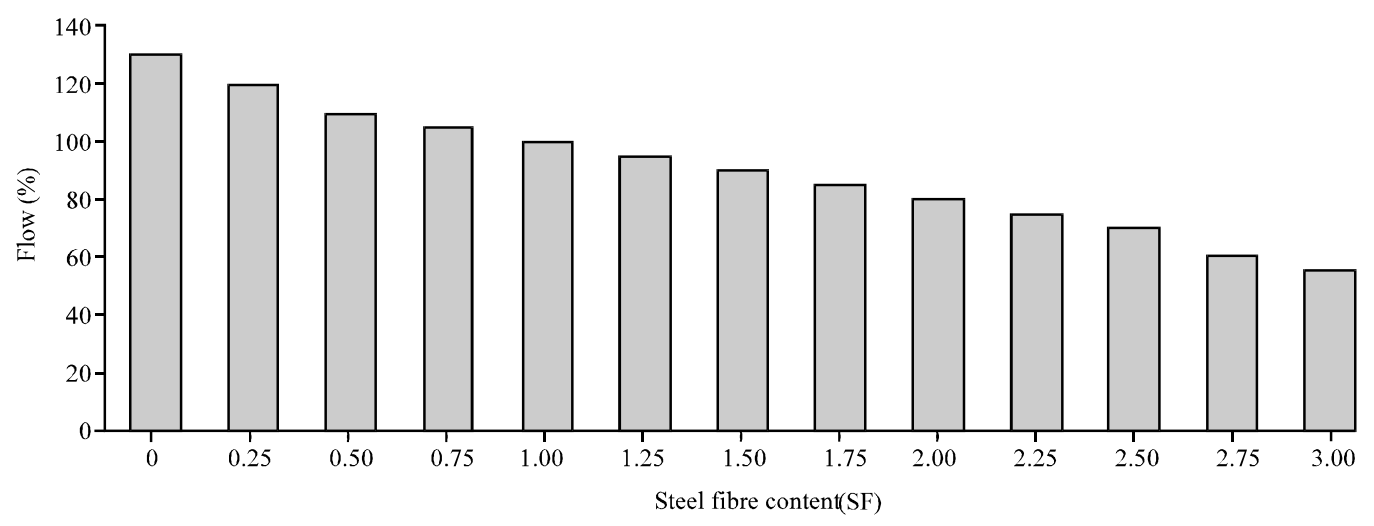

Fig. 7: Effect of steel fiber on flow of geopolymer mortar

because the steel fibers do not participate aggressively in sharing load in the direction of compression loading as a result of not experienced the stretching and straining of fibers (Karunanithi and Anandan, 2014; Amer Mohamed Ibrahim et al., 2017; Wissam D. Salman et al., 2018 and Ahmed Abdullah Mansor et al., 2018). When adding steel fibers to the geopolymer mortar at different doses ranging from $(0.25-3.0 \%)$ with an increase of $0.25 \%$, the optimum ratio of steel fiber content was $2.25 \%$. The increment in compressive, splitting tensile and flexural strength were found to be about $81.79,141.67$ and $207.59 \%$ when $2.25 \%$ steel fibers were added to the geopolymer mortar, respectively. The improvement in the flexural strengths and splitting tensile might be refered to the crack bridging ability of the fibers where by tensile stress was carried through the fibers and delayed spread of cracks giving increase to flexural strength and tensile of the geopolymer mortar (Fig.8-16). 


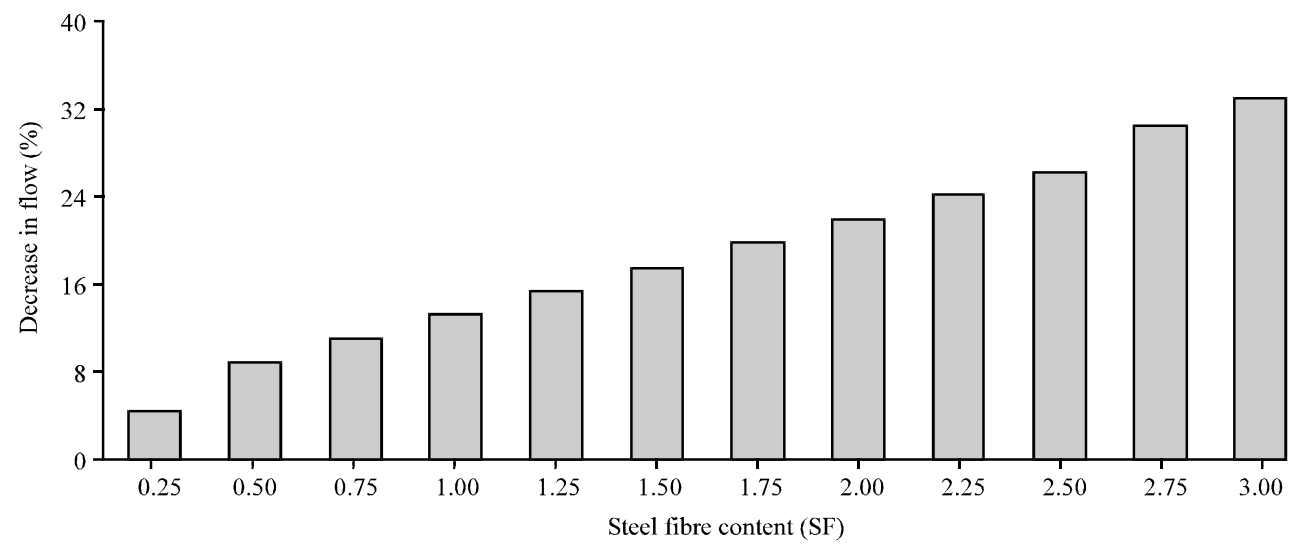

Fig. 8: Decreasing of workability due to steel fiber on geopolymer mortar

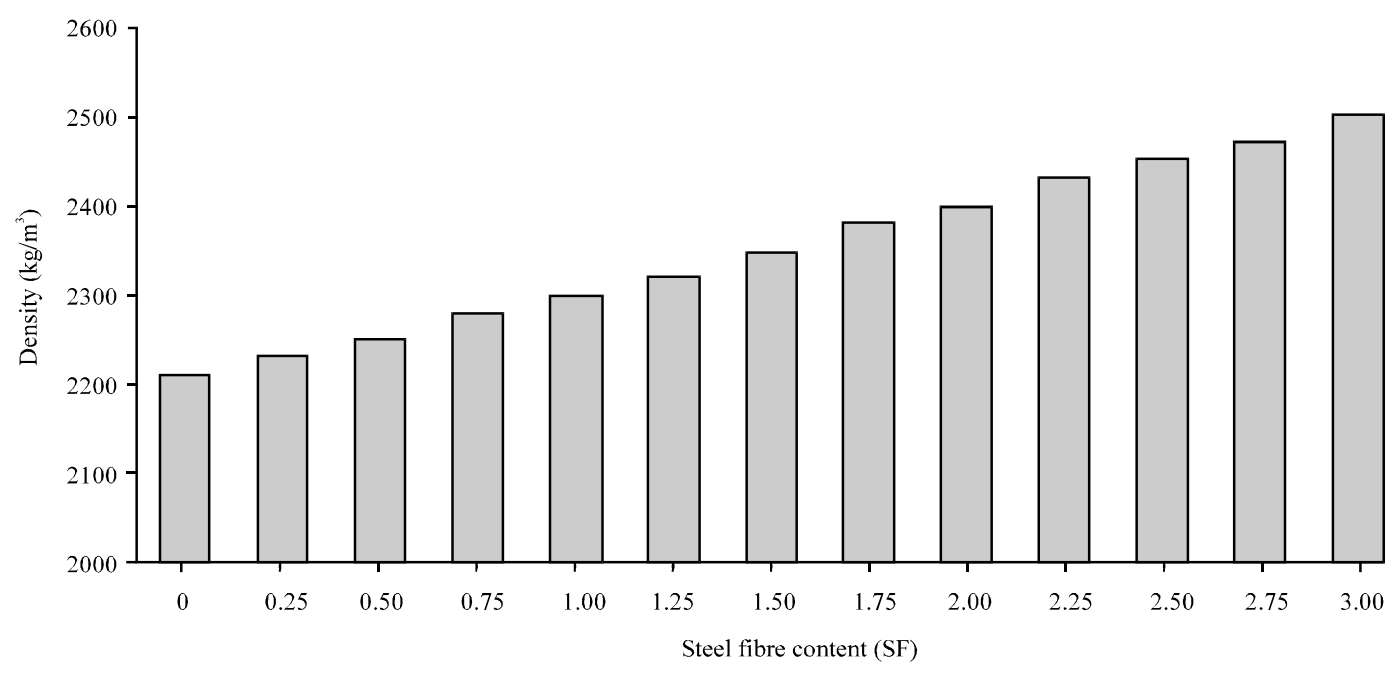

Fig. 9: Effect of steel fiber content on fresh unit weight of geopolymer mortar

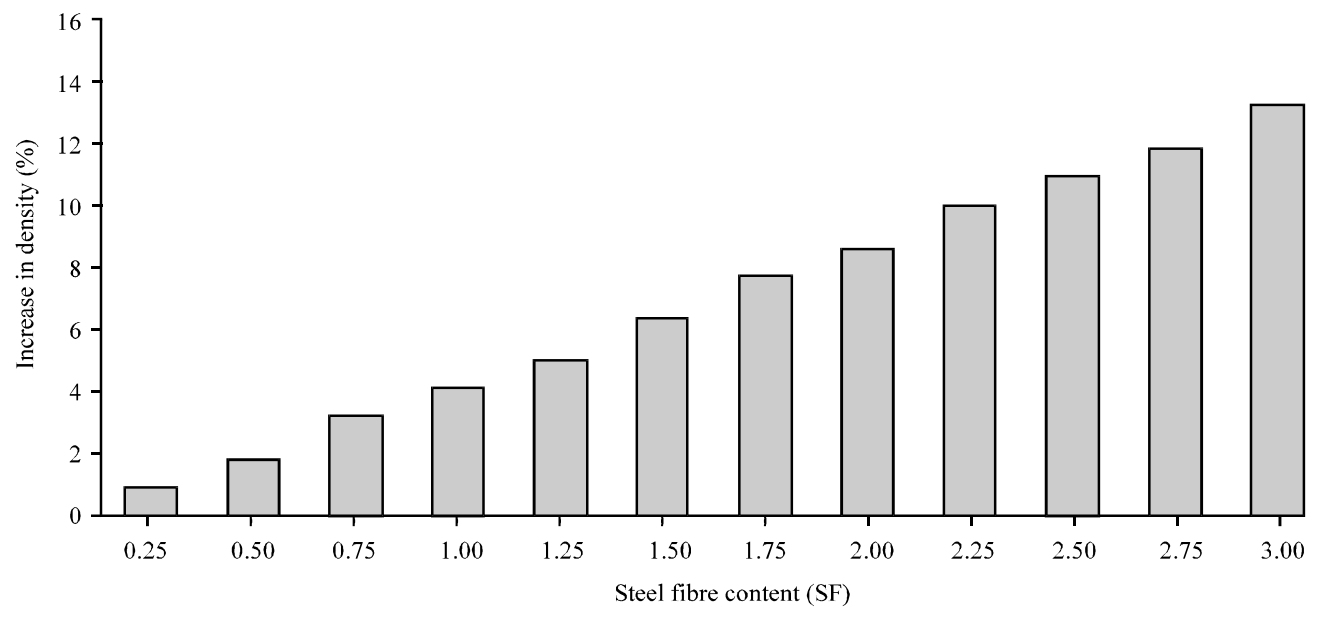

Fig. 10: Fresh unit weight increasing due to steel fiber in geopolymer mortar 


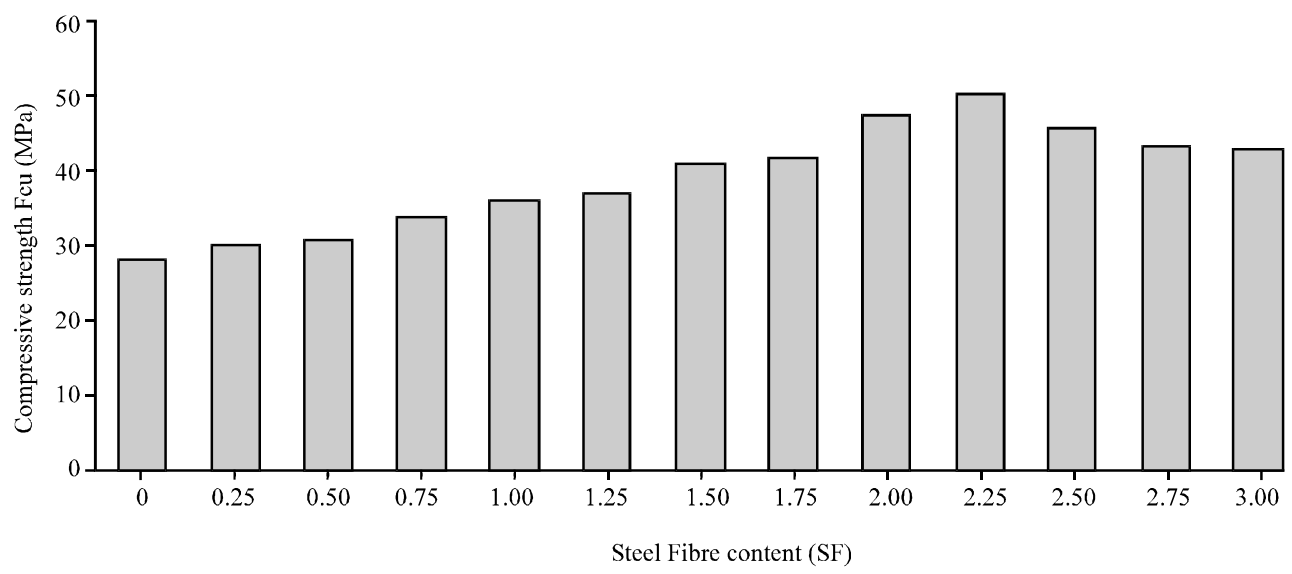

Fig. 11: Effect of steel fibersratio on geopolymer mortar compressive strength

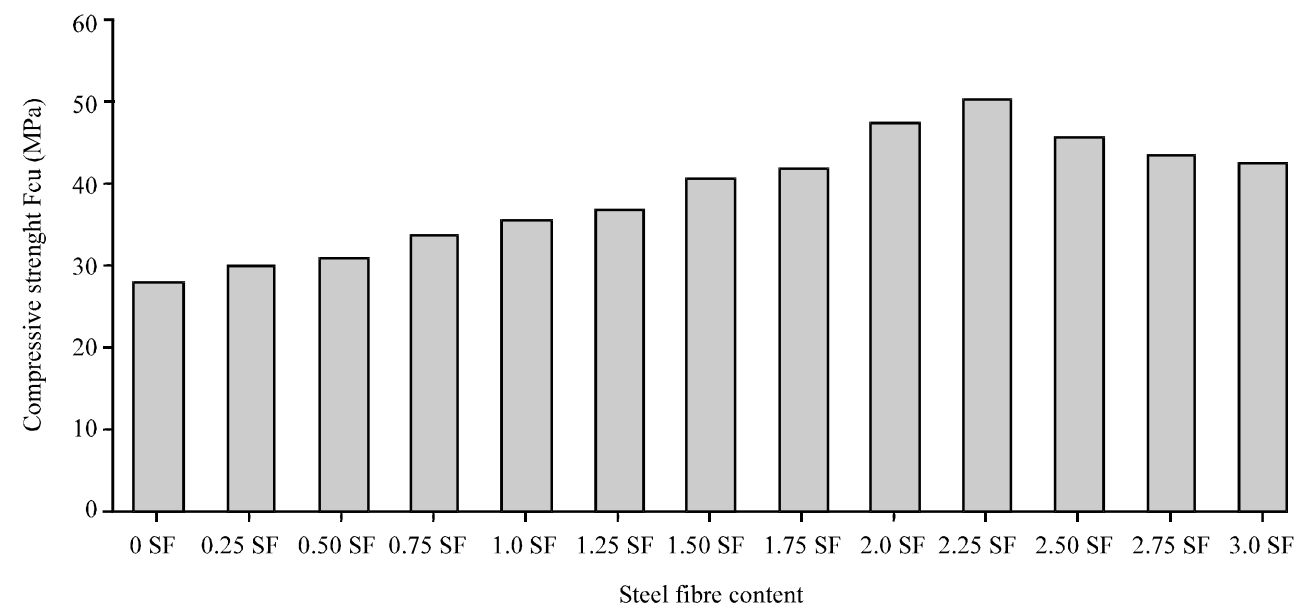

Fig. 12: Percentage increasing in compressive strength due to steel fiber in geopolymer mortar

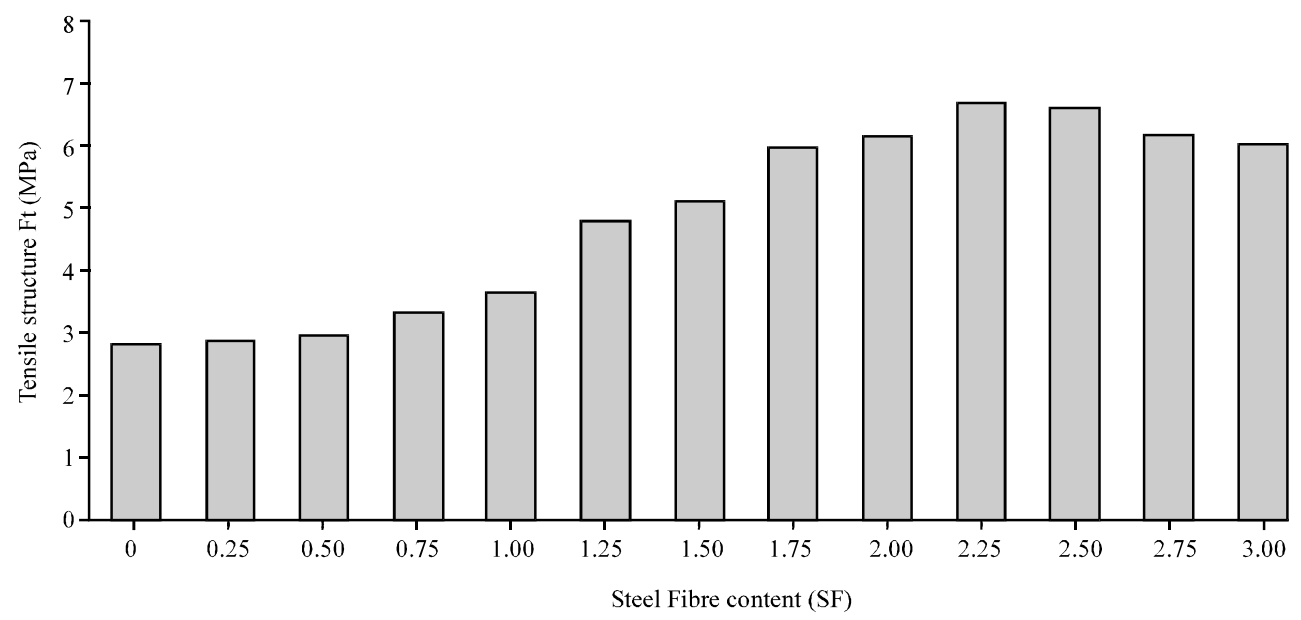

Fig. 13: Effect of steel fibersratio on geopolymer mortar splitting tensile strength 


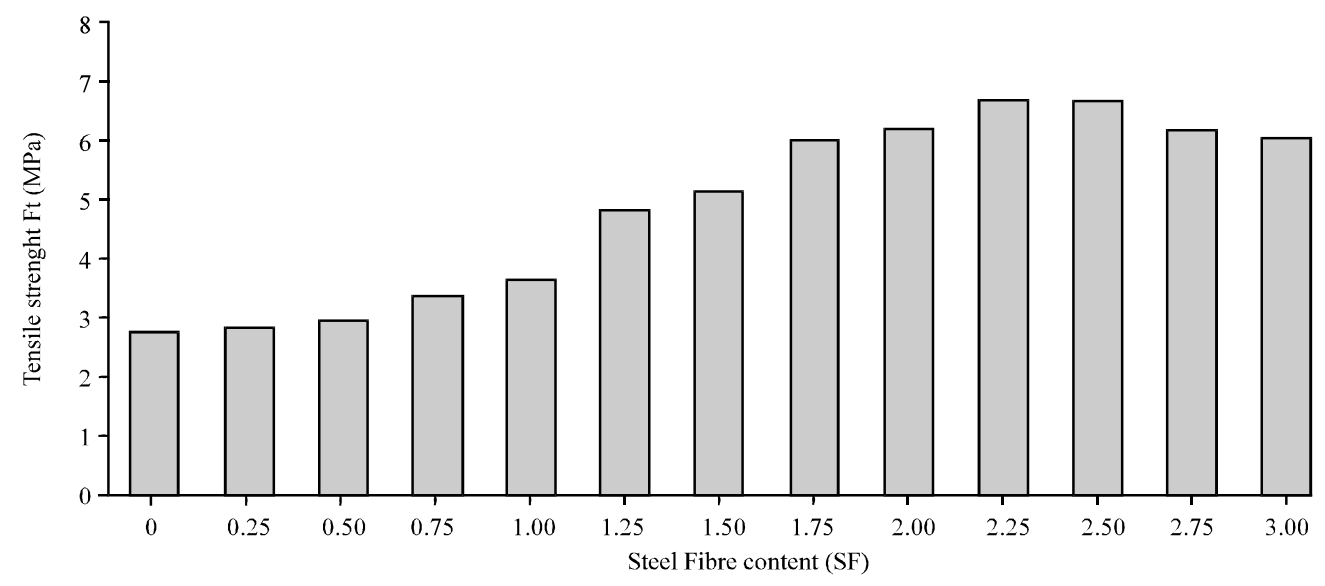

Fig. 14: Increasing in geopolymer mortar splitting tensile strength due to steel fiber

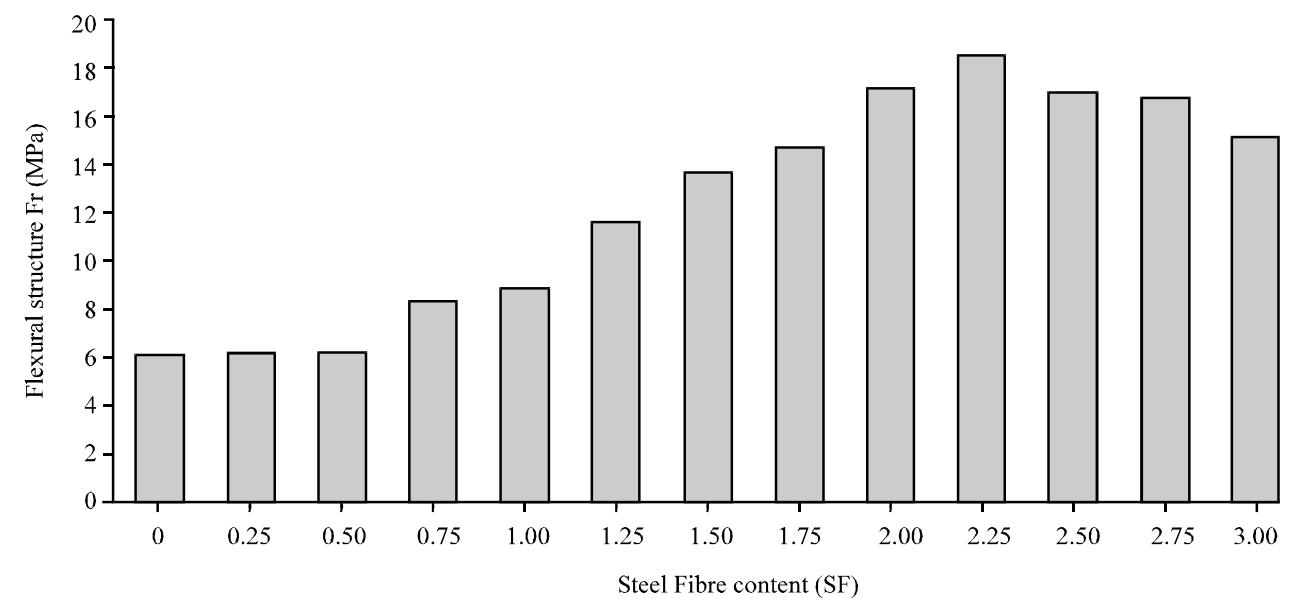

Fig. 15: Effect of steel fibersratio on geopolymer mortar flexural strength

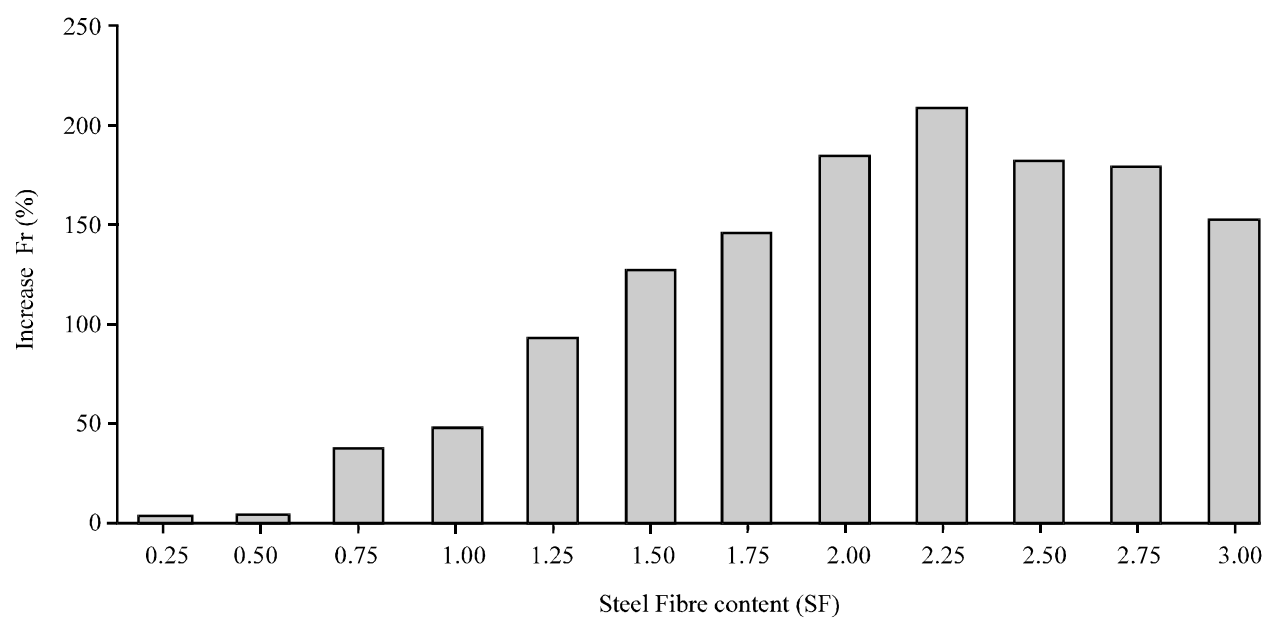

Fig. 16: Increasing in geopolymer mortar flexural strength due to steel fiber 


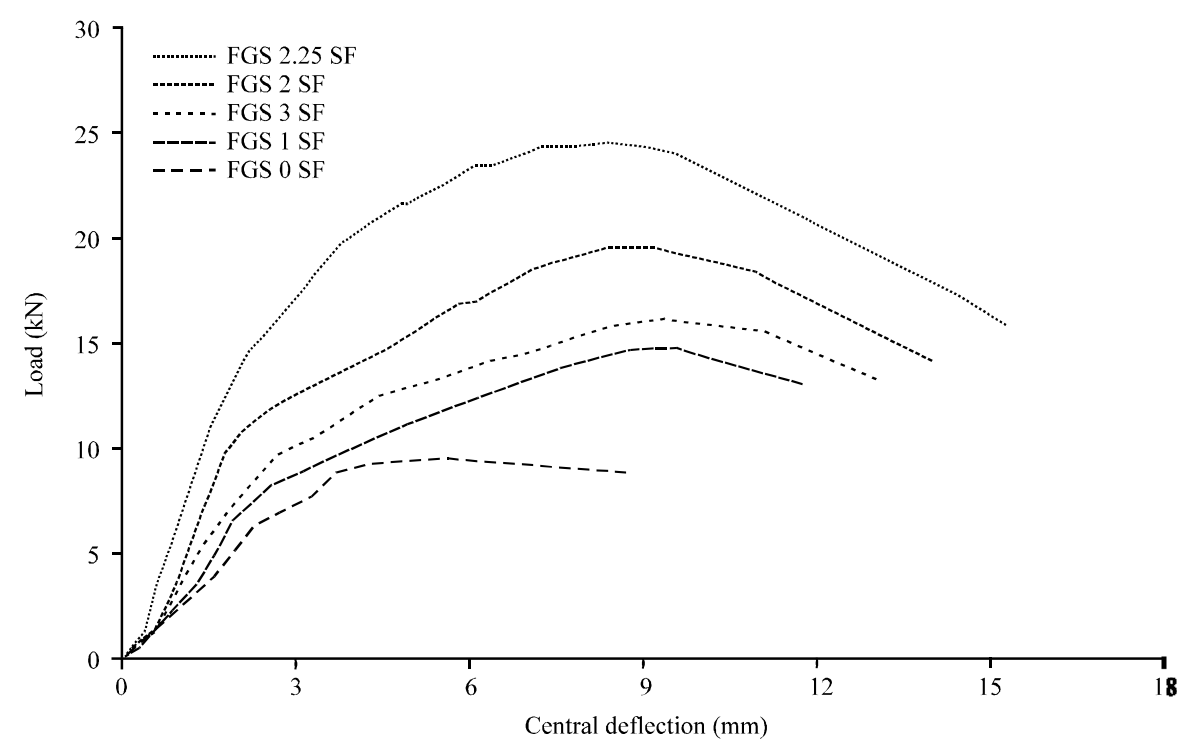

Fig. 17: Load-deflection curve of ferro geopolymer slabs

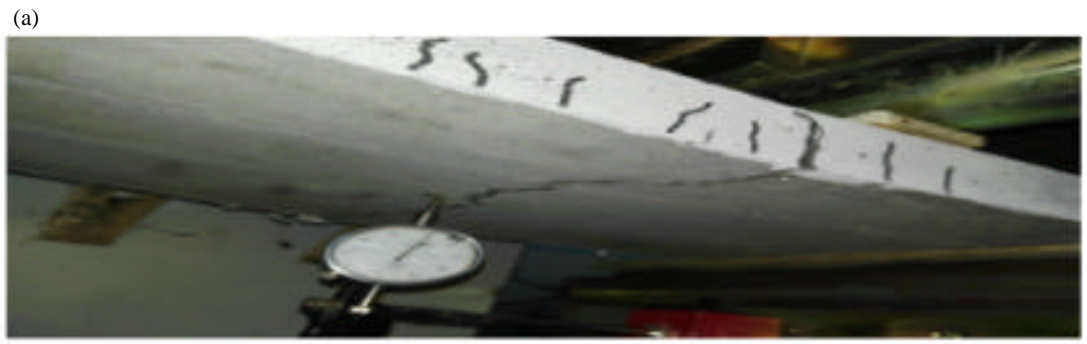

(b)

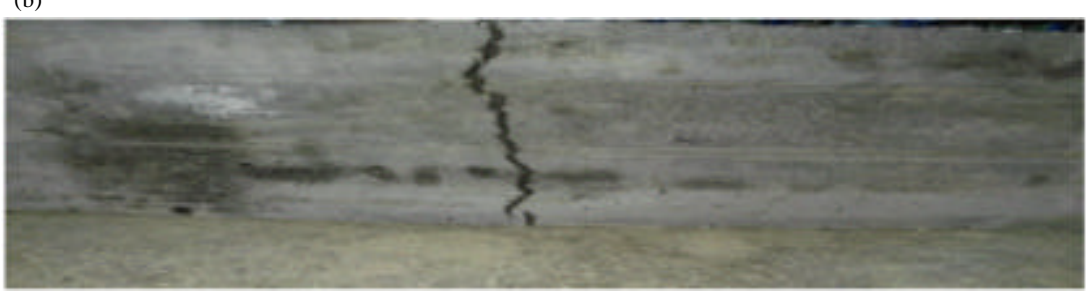

(c)

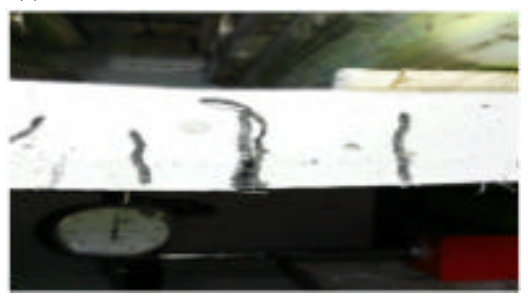

(d)

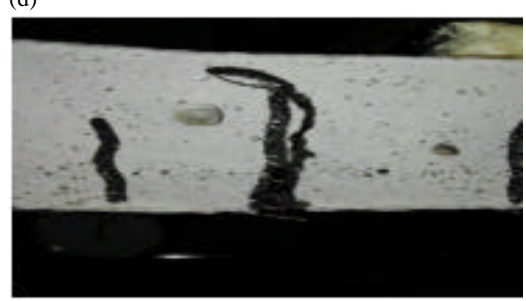

Fig. 18: a-d) Typical Failure of ferro geopolymer slab with steel fibers

Flexural behavior of ferro geopolymer slabs: All ferro geopolymer slabs were tested two concentrated loads by hydraulic machine with capacity is $600 \mathrm{kN}$. The defection measured by $0.01 \mathrm{~mm}$ dial gauges with $50 \mathrm{~mm}$ range fixed under the points loading. After each interval of load increment the deflections and crack width were measured. The results of all tested specimens presented in Table 9. Figure 17 showed the load deflection curves for all slab specimensand Fig. 18 presented the typical failure mode of a tested ferro geopolymer slab specimen with steel 
Table 9: Test results of ferro-geopolymer slabs

\begin{tabular}{|c|c|c|c|c|c|c|c|c|c|c|}
\hline \multirow[b]{2}{*}{ Specimens (SF) } & \multicolumn{2}{|c|}{ Cracking stage } & \multicolumn{2}{|c|}{ Yielding stage } & \multicolumn{2}{|c|}{ Ultimate stage } & \multirow[b]{2}{*}{$\mathrm{P}_{c r} / \mathrm{P}_{\mathrm{u}}(\%)$} & \multicolumn{3}{|l|}{ Load increasing } \\
\hline & $\mathrm{P}_{\mathrm{cr}}(\mathrm{kN})$ & $\mathrm{sr}(\mathrm{mm})$ & $\mathrm{P}_{\mathrm{V}}(\mathrm{kN})$ & ${ }_{\mathrm{H}}(\mathrm{mm})$ & $P_{n}(k N)$ & $.4(\mathrm{~mm})$ & & Increase $\mathrm{P}_{c r}(\%)$ & Increase $\mathrm{P}_{\mathrm{y}}(\%)$ & Increase $P_{u}(\%)$ \\
\hline FGS 0 & 4.43 & 1.47 & 7.56 & 2.65 & 9.57 & 7.09 & 46.29 & Ref. & Ref. & Ref. \\
\hline FGS 1 & 7.36 & 1.59 & 8.15 & 2.14 & 14.69 & 9.58 & 50.10 & 66.14 & 7.80 & 53.50 \\
\hline FGS 2 & 9.20 & 1.40 & 13.00 & 2.69 & 19.60 & 11.40 & 46.94 & 107.67 & 71.96 & 104.81 \\
\hline FGS 2.25 & 12.50 & 1.49 & 17.29 & 2.52 & 24.46 & 12.42 & 51.10 & 182.17 & 128.70 & 155.59 \\
\hline FGS 3 & 7.70 & 1.65 & 10.18 & 2.51 & 16.00 & 10.61 & 48.13 & 73.81 & 34.66 & 67.19 \\
\hline
\end{tabular}

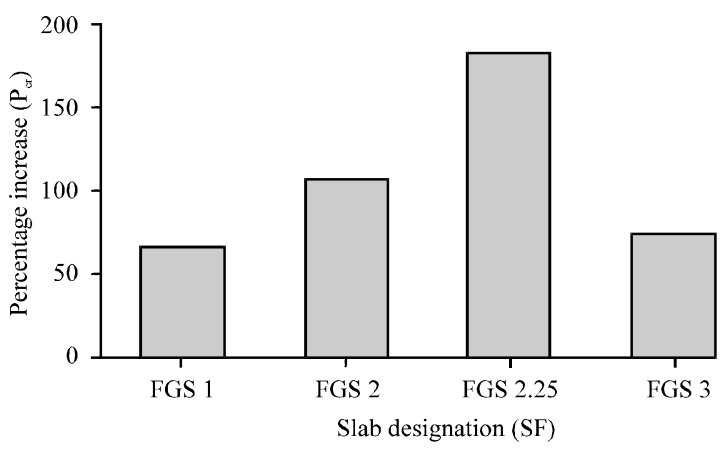

Fig. 19: Increasing in cracking load due to steel fibers in ferro-geopolymer slabs

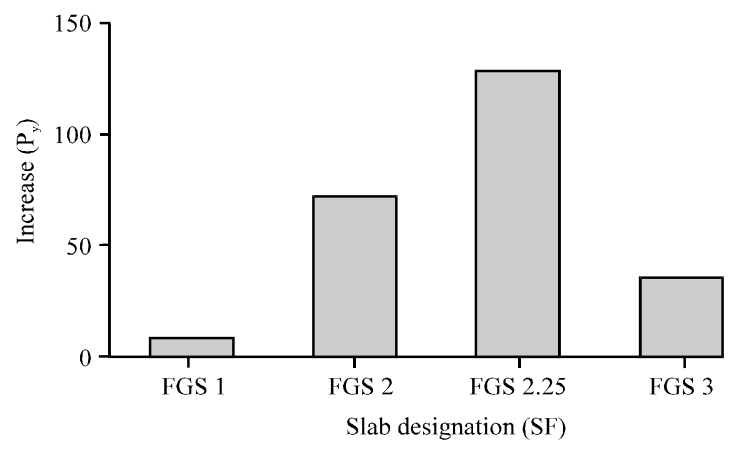

Fig. 20: Increasing in yielding load due to steel fibers in ferro-geopolymer slabs

fibers. The behavior of ferro geopolymer slab specimen can be considered by three distinct stages as shown in Fig. 17. In stage 1, all the material is elastic, so, it can be nominated as pre-cracking stage, so, the cracking load can be expected by the linear elastic theory and the relationship of load-deflection curve is a linearas well. During stage 2 a multi cracks appear after geopolymer mortar cracking due to transmission of load from geopolymer mortar to the steel fiber and wire mesh. Final stage is consider a failure of specimen where wide of current cracks with increasing of applied load. Actully, in final stage the load is mainly carried by the steel fibers and mesh. From Table 9 and Fig. 19-21 shows the test results of ferro geopolymer slabs with and without steel
Table 10: Cracking of ferro-geopolymer slabs at ultimate stage

\begin{tabular}{lccc} 
Specimens (SF) & Width of crack (mm) & $\begin{array}{c}\text { Number of } \\
\text { cracks }\end{array}$ & $\begin{array}{c}\text { Crack spacing } \\
\text { (mm) }\end{array}$ \\
\hline FGS 0 & 0.322 & 6 & 21.28 \\
FGS 1 & 0.293 & 8 & 18.63 \\
FGS 2 & 0.225 & 9 & 16.42 \\
FGS 2.25 & 0.196 & 10 & 15.15 \\
FGS 3 & 0.144 & 10 & 12.27 \\
\hline
\end{tabular}

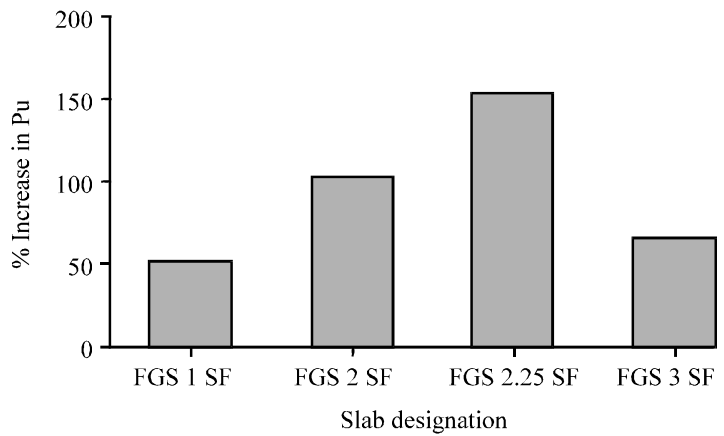

Fig. 21: Increasing in ultimate load due to steel fibers in ferro-geopolymer slabs

fibers. It can be observed that by using steel fibers the load capacity of ferro geopolymer slab panel is greater than the slab panels haven't steel fiber delayed a first crack appear and increased in crack, yield and ultimate loads compared to without fibers first crack is appeared at about $45-50 \%$ of ultimate load larger deflections in steel fibers reinforced ferro geopolymer specimens compared to specimens without steel fibers at ultimate loads improved ductility by used the steel fiber reinforced ferro geopolymer specimens compared to similar specimens without fibers by undergoing large deformation at ultimate load the crack, yield, ultimate loads and stiffness of the specimen with $2.25 \%$ steel fiber is upper than that of the specimens with ( $0-3 \%)$ steel fiber.

Table 10 showed the results of crack width and average crack spacing at ultimate load. It can be observed that by using steel fiber, crack width decreased and number of cracks increased and the average crack spacing is less in the case of ferro geopolymer slab panels with steel fibers compared to those of without steel fiber reinforced panels. 


\section{CONCLUSION}

According to the experimental results of geopolymer mortar and ferro geopolymer slabs without and with steel fibers the following can be stated. Steel fibers presence improved the mechanical properties of geopolymer mortar as well as flexural behavior of ferro geopolymer slabs.

Adding steel fibers to the geopolymer mortar had greater effect in developing the flexural and tensile strength compared to the compressive strength. Similarly, the flexural behavior of ferro geopolymer slabs with steel fibers are found to be greater compared to ferro geopolymer slab haven't steel fibers. Increased steel fiber concentration resulted in less workable mix. Out of all the mix the one with $2.25 \%$ steel fiber content gave a greater mechanical property of geopolymer mortar (flexural, compressive and splitting tensile strengths) and flexural performance of ferro geopolymer slabs.

Mix with $2.25 \%$ steel fiber content can be considered as optimum steel fiber dosage. Beyond certain level $(2.25 \%)$ the addition of steel fibers caused decreasing in mechanical and flexural strength of specimens. Using steel fiber in ferro geopolymer slabsincreased the ductility of because of introduction of steel fiber in the mix. Using steel fiber in ferro geopolymer slabs changed the failure mode from sudden in slabs without steel fiber because of steel fiber in the mix and allows sufficient time before failure after yielding.

By increasing steel fiber contents, initial crack, yield and ultimate loads of the slab's specimens are increased in flexural testing. Increase the steel fiber content of the specimen in the geopolymer mortar and ferro geopolymer slab increased the load capacity and stiffness of the tested specimens and crack width is decreased. In the case of steel fiber ferro geopolymer slabs, the load capacities, energy absorption and deformation are high at ultimate load. In the case of ferro geopolymer slabs with steel fibers, caused delay in crack growth and crack width is decreased, however, number of cracks is increased. Test results will be useful for damage tolerant design of ferro geopolymer structural components subjected to variety of loadings. In corporation of steel fibers at $2.25 \%$ in ferro geopolymer slabs, increased the load capacity with $155.59 \%$ and decreased in deflection $75.18 \%$.

\section{REFERENCES}

ASTM, 2003. Standard Specification for Coal Fly Ash and Raw or Calcined Natural Pozzolan for use in Concrete. ASTM International, West Conshohocken, Pennsylvania, USA.,
Abdullah, K. Takiguchi, K. Nishimura and S. Hori, 2013. Behavior of ferrocement subjected to missile impact. Proceedings of the Transactions of the 17th International Conference on Structural Mechanics in Reactor Technology (SmiRT 17), August 17-22, 2003, IASMiRT Publisher, Czech Republic, Europe, pp: 1-6.

Aydin, S. and B. Baradan, 2013. The effect of fiber properties on high performance alkali-activated slag/silica fume mortars. Compos. Part B. Eng., 45: 63-69.

Balaguru, P.N. and G.B. Batson, 1997. State-of-the-Art Report on Ferrocement. American Concrete Institute, Michigan, USA.,

Balaguru, P.N. and S.P. Shah, 1992. Fibre Reinforced Cement Composites. McGraw-Hill, New York, USA., ISBN:9780070564008, Pages: 530.

Barros, J.A.O. and J.S. Cruz, 2001. Fracture energy of steel fiber-reinforced concrete. Mech. Compos. Mater. Structur., 8: 29-45.

Bernal, S., R. de Gutierrez, S. Delvasto and E. Rodriguez, 2010. Performance of an alkali-activated slag concrete reinforced with steel fibers. Constr. Build. Mater., 24: 208-214.

Day, R.L. and C. Shi, 1994. Effect of initial water curing on the hydration of cements containing natural pozzolan. Cement Concr. Res., 24: 463-472.

Ezeldin, A. and P. Balaguru, 1989. Bond behavior of normal and high-strength fiber reinforced concrete. Mater. J., 86: 515-524.

Ganesan, N., P.V. Indira and M.V. Sabeena, 2013. Tension stiffening and cracking of hybrid fiber-reinforced concrete. ACI. Mater. J., 110: 715-722.

Ghavami, K., 2005. Bamboo as reinforcement in structural concrete elements. Cem. Concr. Compos., 27: 637-649.

Gokulram, H. and R. Anuradha, 2013. Strength studies on polypropylene fibre reinforced geo-polymer concrete using M-sand. J. Emerging Trends Eng. Dev., 2: 242-250.

Hardjito, D. and B.V. Rangan, 2005. Development and properties of low-calcium fly ash-based geopolymer concrete. Master Thesis, Curtin University, Perth, Western Australia.

Hassanpour, M., P. Shafigh and H.B. Mahmud, 2012. Lightweight aggregate concrete fiber reinforcement-a review. Constr. Build. Mater., 37: 452-461.

Joseph, B. and G. Mathew, 2012. Influence of aggregate content on the behavior of fly ash based geopolymer concrete. Sci. Iranica, 19: 1188-1194. 
Kaid, N., M. Cyr, S. Julien and H. Khelafi, 2009. Durability of concrete containing a natural pozzolan as defined by a performance-based approach. Constr. Build. Mater., 23: 3457-3467.

Karunanithi, S. and S. Anandan, 2014. Flexural Toughness Properties of Reinforced Steel Fibre Incorporated Alkali Activated Slag Concrete. Adv. Civil Eng., 2014: 1-12.

Koksal, F., F. Altun, I. Yigit and Y. Sahin, 2008. Combined effect of silica fume and steel fiber on the mechanical properties of high strength concretes. Constr. Build. Mater., 22: 1874-1880.

Kuder, K.G. and S.P. Shah, 2010. Processing of high-performance fiber-reinforced cement-based composites. Constr. Build. Mater., 24: 181-186.

Kumar, V.S., B.S. Thomas and A. Christopher, 2012. An experimental study on the properties of glass fibre reinforced geopolymer concrete. Intl. J. Eng. Res. Appl., 2: 722-726.

Lau, A. and M. Anson, 2006. Effect of high temperatures on high performance steel fibre reinforced concrete. Cement Concr. Res., 36: 1698-1707.

Li, X., 2009. Recycling and reuse of waste concrete in China: Part II. structural behaviour of recycled aggregate concrete and engineering applications. Resour. Conserv. Recycl., 53: 107-112.

Lin, V.W.J., S.T. Quek and M. Maalej, 2011. Static and dynamic tensile behaviour of PE-fibrous ferrocement. Mag. Concr. Res., 63: 61-73.

Lloyd, N.A. and V.B. Rangan, 2010. Geopolymer concrete with fly ash. Proceedings of the 2nd International Conference on Sustainable Construction Materials and Technologies, June 28-30, 2010, Marche Polytechnic University, Ancona, Italy, ISBN:978-1-4507-1490-7, pp: 1-12.

McLellan, B.C., R.P. Williams, J. Lay, A. van Riessen and G.D. Corder, 2011. Costs and carbon emissions for geopolymer pastes in comparison to ordinary portland cement. J. Cleaner Prod., 19: 1080-1090.

Mermerdas, K., S. Manguri, D.E. Nassani and S.M. Oleiwi, 2017. Effect of aggregate properties on the mechanical and absorption characteristics of geopolymer mortar. Eng. Sci. Technol. Intl. J., 20: 1642-1652.

Mo, K.H., U.J. Alengaram and M.Z. Jumaat, 2014. A review on the use of agriculture waste material as lightweight aggregate for reinforced concrete structural members. Adv. Mater. Sci. Eng., 2014: 1-9.
Mo, K.H., U.J. Alengaram and M.Z. Jumaat, 2016. Structural performance of reinforced geopolymer concrete members: A review. Constr. Build. Mater., 120: 251-264.

Natali, A., S. Manzi and M.C. Bignozzi, 2011. Novel fiber-reinforced composite materials based on sustainable geopolymer matrix. Proc. Eng., 21: 1124-1131.

Nili, M. and V. Afroughsabet, 2012. Property assessment of steel-fibre reinforced concrete made with silica fume. Constr. Build. Mater., 28: 664-669.

Pan, Z., J.G. Sanjayan and B.V. Rangan, 2009. An investigation of the mechanisms for strength gain or loss of geopolymer mortar after exposure to elevated temperature. J. Mater. Sci., 44: 1873-1880.

Phalke, R.J. andD.G. Gaidhankar, 2014. Flexural behaviour of ferrocement slab panels using welded square mesh by incorporating steel fibres. Intl. J. Res. Eng. Technol., 3: 756-763.

Rajendran, M. and N. Soundarapandian, 2013. An experimental investigation on the flexural behavior of geopolymer ferrocement slabs. J. Eng. Technol., 3: 97-104.

Rangan, B.V., 2008. Fly ash-based geopolymer concrete. Ph.D Thesis, Curtin University of Technology, Perth, Australia.

Rao, T.C., T.D.G. Rao and N.V.R. Rao, 2008. An experimental study on Ferro cement channel units under flexural loading. Intl. J. Mech. Solid., 3: 195-203.

Rekha, K.P. and R. Hazeena, 2014. Strength and durability of fibre reinforced geopolymer concrete. Intl. J. Sci. Eng. Res., 5: 412-416.

Sayyad, A.S. and S.V. Patankar, 2013. Effect of steel fibres and low calcium fly ash on mechanical and elastic properties of geopolymer concrete composites. Indian J. Mater. Sci., 2013: 1-8.

Shannag, M.J. and A. Yeginobali, 1995. Properties of pastes, mortars and concretes containing natural pozzolan. Cement Concr. Res., 25: 647-657.

Sivakumar, A. and M. Santhanam, 2007. A quantitative study on the plastic shrinkage cracking in high strength hybrid fibre reinforced concrete. Cem. Concr. Comp., 29: 575-581.

Song, P.S., S. Hwang and B.C. Sheu, 2005. Strength properties of nylon-and polypropylene-fiberreinforced concretes. Cement Concr. Res., 35: 1546-1550.

Srinivasan, P.A., V. Poornima, S. Sowthamirajan and R. Venkatasubramani, 2013. Study on mechanical properties of polypropylene fibre reinforced geopolymer concrete. Intl. J. Emerging Trends Eng. Dev., 2: 21-31. 
Sudhikumar, G.S., K.B. Prakash and M.V.S. Rao, 2014. Effect of aspect ratio of fibers on the strength characteristics of slurry infiltrated fibrous ferrocement. Intl. J. Struct. Civil Eng. Res., 3: 29-37.

Toutanji, H., N. Delatte, S. Aggoun, R. Duval and A. Danson, 2004. Effect of supplementary cementitious materials on the compressive strength and durability of short-term cured concrete. Cement Concr. Res., 34: 311-319.

Toutanji, H.A., 1999. Properties of polypropylene fiber reinforced silica fume expansive-cement concrete. Constr. Build. Mater., 13: 171-177.
Vijai, K., R. Kumutha and B.G. Vishnuram, 2012. Effect of inclusion of steel fibres on the properties of geopolymer concrete composites. Asian J. Civil Eng. Build. Hous., 13: 377-385.

Vogel, H.M. and D. Svecova, 2012. Evaluation of elastic modulus for high-strength concrete. ACI. Mater. J., 109: 313-322.

Xiao, J., W. Li, Y. Fan and X. Huang, 2012. An overview of study on recycled aggregate concrete in China (1996-2011). Construction Build. Mater., 31: 364-383.

Yurtseven, A.E., 2004. Determination of mechanical properties of hybrid fiber einforced concrete. MSc Thesis, Middle East Technical University, Ankara, Turkey. 